\title{
Proceeding
}

Supplementary Issue: Winter Conferences of Sports Science. Costa Blanca Sports Science Events, 22-23 March 2021. Alicante, Spain.

\section{Influence of sports practice on academic performance in football players}

BEATRIZ SILVIA SURICHAQUI-TIZA $\checkmark$, MARCO ANTONIO TEJADA, LUCIA MIREYA SORIAVILLANUEVA, QUITERIO TRUJILLO-REYNA

San Marcos National University, Peru

\begin{abstract}
The purpose of this research work was to evaluate the influence of sports practice on academic performance in students of the Physical Education career of a Peruvian state university who play soccer in their free time in 2019. The sampling was non-probabilistic and for convenience, being made up of a total of 113 students. The physical activity habits questionnaire with a reliability of 0.70 and the record of grades for the basic mathematics subject were used. The data was processed using SPSS v. 24. Among the results, a significant difference was obtained between sports practice and its dimensions, being higher in the male gender $(p$ $<.05)$. Similarly, a positive and significant correlation was obtained $(r=0.33, p=.000)$; furthermore, sports practice and its dimensions have a significant impact on academic performance $\left(r^{2}=10 \%, p<.05\right)$. These findings make a valuable contribution to answering some key questions about physical activity and its role in academic achievement.

Keywords: Sports practice; University sports management; Physical activity practice; Academic performance.

Cite this article as:

Surichaqui-Tiza, B.S., Tejada, M.A., Soria-Villanueva, L.M., \& Trujillo-Reyna, Q. (2021). Influence of sports practice on academic performance in football players. Journal of Human Sport and Exercise, 16(3proc), S1016-S1022. https://doi.org/10.14198/jhse.2021.16.Proc3.18
\end{abstract}

Corresponding author. National University of San Marcos, Peru. https://orcid.org/0000-0002-4550-2210

E-mail: beatriz.surichaqui@unmsm.edu.pe

Abstract submitted to: Winter Conferences of Sports Science. Costa Blanca Sports Science Events, 22-23 March 2021. Alicante, Spain.

JOURNAL OF HUMAN SPORT \& EXERCISE ISSN 1988-5202.

(c) Faculty of Education. University of Alicante.

doi:10.14198/jhse.2021.16.Proc3.18 


\section{INTRODUCTION}

At present, the society is dominated by inactive lifestyle, stress and aggressiveness (Alvarez et al., 2017). Most of the population around the world does not perform sports activities, because they do not know about the advantages that these kinds of activities have on the body, so they are unaware of the fact that performing physical activity (PA) in a systematic and regular way can lead to an improvement in the quality of life (Georgian and Lorand, 2016).

For this reason, during the last decade, sports associations have become increasingly concerned with the educational experience of students who practice a sport, beyond the application of eligibility rules and regulations (Gayles and $\mathrm{Hu}, 2009$ ). Previous research revealed that regular PA can help on maintaining good health levels and preventing diseases such as hypertension, obesity, metabolic syndrome, heart disease, among others. PA produces important benefits at the psychosocial level (Arias et al., 2015; Ramírez et al., 2018). Sports in the college stage allow for character building, give essential training for success, also develop abilities for teamwork, discipline, and achievement (Khan et al., 2014).

On the other hand, universities consider that it is a major objective to enhance the academic performance (AP) of students, since it can significantly affect the lifestyle of students. As well, AP is predominant to establish how much students have learned and whether students will continue in the careers they are in (Şahin et al., 2018; Asgari and Carter Jr, 2016), since a university degree is essential for a student-athlete transition to life after sports (Gill Jr and Farrington, 2014).

In terms of sports practice and AP, there is national and international research, as is the case of McPherson et al. (2018), who identified a significant relation between PA and AP $(r=0.225)$ of schoolchildren; as well as Coe et al. (2006), who specify that the grades were similar regardless of whether the students were enrolled in physical education during the first or second semester and sports practice did not affect these grades. In addition to Dwyer et al. (2001), who obtained as a result that PA improves AP; likewise, Donnelly and Lambourne (2011) indicated that moderate sports practice improved AP by $6 \%(p<.02)$. On the flip side, Taras (2005), who indicated that although it is true there may be some short-term improvements in PA, such as concentration in studies, the long-term improvement in AP as a result of PA is not well founded.

Although it is true at the university level, there are several studies that have analysed the sports practice and AP variable (Montecalbo-Ignacio et al., 2017; Yıldırım and Bayrak, 2019; Lipošek et al., 2019; Muñoz-Bullón et al., 2017; Qurban et al., 2018; Al-Drees et al., 2016; Fricke et al., 2017). There is still no research that analyses both variables in Physical Education students who practice soccer in their free time.

Due to the aforementioned, this research has the following objectives: a) to compare the levels of sports practice and AP according to gender, b) to determine the relationship betwixt sports practice, its dimensions and $\mathrm{AP}$ and $\mathrm{c}$ ) to contrast the influence of sports practice and its dimensions on AP.

\section{METHOD}

\section{Participants}

The sampling was non-probabilistic and for convenience, consisting of 113 students of the Physical Education career, $76.1 \%$ men and $23.9 \%$ women, who play soccer with ages betwixt $19-27$ years old during the academic period 2019-1 and 2019-2 in a state university in Lima. The convenience sample (Etikan et al., 2016) is a kind of non-probability sampling where the individuals of the target audience with certain criteria, 
for instance accessibility, geographic proximity and availability at a certain time to participate, are incorporated for the objective of the investigation.

\section{Measurements}

To evaluate sports practice, Castillo et al. (2012), designed a questionnaire on sports practices for university students using the Delphi method. The reliability of the questionnaire was 0.70 , that according to Taber (2018) the indicator must reach 0.70 for an instrument to have an adequate level of internal consistency. The instrument was subdivided into 3 parts: a) university sports management, thus refers to the coordination of different sources, technologies, processes and ad-hoc situations in order to attain efficient production and the exchange of sports services (Retar et al., 2015), whereby consists of the use of facilities at the university, sports card, satisfaction in the facilities, schedule, among others; and money used for sports practice, b) PA practice, which looks into to all kind of movement as part of an individual's work or entertainment. In that way, a good level of PA improves health (World Health Organization, 2020), thus is made up of place of practice, warm-up and hygiene, c) psychosocial aspects of the practice of physical-sporting activity, that refers to the management of stress and anxiety, improved self-esteem, emotional intelligence, among others (Nieman, 2002). In this case, motivation, age at which it started and company during sports practice were taken into account.

To evaluate AP, the students' mathematics course grades corresponding to the final grades of the academic year 2019-1 and 2019-2 were used. The marks of each of the subjects were taken on a scale of 0 to 20 points.

\section{Procedures}

The inclusion criteria were that the students play soccer and that they are enrolled in the academic periods under study at the time of completing the questionnaires. To fill out the questionnaire, the students were contacted by email (Google Forms) and in person (paper format). It is important to mention that participation in the study was voluntary, the anonymity of the responses was guaranteed and the obtaining of informed consents. All participants received the same information about the study topic and how they should complete the questionnaire in an average time of 10-20 minutes.

\section{Analysis of data}

Descriptive analysis was performed using the mean and standard deviation. Likewise, the correlations linking sports practice, its dimensions and AP were analysed. To determine the influence on AP, the multiple regression model was used, having as predictive variables the university sports management, the practice of PA and psychosocial aspects of the practice of physical-sports activity. As stated by Uyanık and Güler (2013), regression analysis is a statistical technique that allows estimating the relationship in the middle of variables, from which a linear equation is formulated; in the case of multiple linear regression, the dependent variables are analysed on an independent variable. For data analysis we used the statistical program IBM SPSS v.24 with a fixed significance level of $p<.05$.

\section{RESULTS}

Table 1 exposes the averages and standard deviations (SD) of the dimensions of sports practice in relation to the student's gender. It is highlighted that there are significant differences in university sports management, being higher in the male gender $(p=.04)$, as well as with the practice of PA $(p=.044)$ and in the psychosocial aspects of the practice of PA sports $(p=.005)$. On the other hand, there were no significant differences in $\operatorname{AP}(p=.275)$, but a higher level was observed in the female gender. 
Table 1. Comparison of levels of sports practice, dimensions and AP.

\begin{tabular}{lccc}
\hline & Male & Female & \\
& $n=86$ & $n=27$ & Sig. \\
& Mean (SD) & Mean (SD) & \\
\hline Sport practice & $36.8(6.33)$ & $31.33(6.68)$ & .00 \\
University sports management & $21.27(3)$ & $18.9(5.3)$ & .04 \\
PA practice & $7.52(3.1)$ & $6.22(2.15)$ & .044 \\
Psychosocial aspects of the practice of physical-sporting activity & $8.04(3.03)$ & $6.22(2.33)$ & .005 \\
AP $\quad 13.95(3.8)$ & $14.9(4)$ & .275 \\
\hline \multicolumn{2}{c}{ Note: PA: Physical activity; AP: Academic performance; $n$ : sample; SD: standard deviation. }
\end{tabular}

Table 2 shows the correlations allying sports practice, its dimensions and AP The correlations of sports practice with university sports management $(r=0.71)$, PA practice $(r=0.7)$, psychosocial aspects of sportsPA practice $(r=0.62)$ and AP are significant and positive. $(p=.000)$. University sports management is positively correlated with the practice of PA $(r=0.266)$, psychosocial aspects of the practice of physicalsports activity $(r=0.138)$ and with AP in a significant way $(r=0.33, p=.027)$. The practice of PA in a positive and significant way with the psychosocial aspects of the practice of physical-sports activity $(r=0.231)$ and with $\mathrm{AP}(r=0.316)$. Finally, the psychosocial aspects of the practice of physical-sporting activity are positively and significantly correlated $(p=.028)$ with AP $(r=0.207)$.

Table 2. Correlations between sports practice, dimensions and academic AP.

\begin{tabular}{|c|c|c|c|c|c|}
\hline & & $\begin{array}{l}\text { Sport } \\
\text { practice }\end{array}$ & $\begin{array}{l}\text { University } \\
\text { sports } \\
\text { management }\end{array}$ & $\begin{array}{l}\text { PA } \\
\text { practice }\end{array}$ & $\begin{array}{l}\text { Psychosocial } \\
\text { aspects of the } \\
\text { practice of } \\
\text { physical- } \\
\text { sporting } \\
\text { activity }\end{array}$ \\
\hline Sport practice & $\begin{array}{l}\text { Spearman coefficient } \\
\text { Sig. }\end{array}$ & 1.000 & & & \\
\hline \multirow{2}{*}{$\begin{array}{l}\text { University } \\
\text { sports } \\
\text { management }\end{array}$} & Spearman coefficient & $.71^{* *}$ & 1.000 & & \\
\hline & Sig. & .000 & & & \\
\hline PA practice & $\begin{array}{l}\text { Spearman coefficient } \\
\text { Sig. }\end{array}$ & $\begin{array}{l}.7^{* *} \\
.000\end{array}$ & $\begin{array}{l}.266^{* *} \\
.004\end{array}$ & 1.000 & \\
\hline \multirow{2}{*}{$\begin{array}{l}\text { Psychosocial } \\
\text { aspects of the } \\
\text { practice of } \\
\text { physical- } \\
\text { sporting activity }\end{array}$} & Spearman coefficient & $.62^{* *}$ & .138 & $.231^{*}$ & 1.000 \\
\hline & Sig. & .000 & .145 & .014 & \\
\hline $\mathrm{AP}$ & $\begin{array}{l}\text { Spearman coefficient } \\
\text { Sig. }\end{array}$ & $\begin{array}{l}.33^{* *} \\
.000\end{array}$ & $\begin{array}{l}.209^{*} \\
.027\end{array}$ & $\begin{array}{l}.316^{* *} \\
.001\end{array}$ & $\begin{array}{l}.207^{*} \\
.028\end{array}$ \\
\hline
\end{tabular}

In table 3 , in relation to $\mathrm{AP}$, when introducing university sports management, $2.3 \%$ of the total variance was explained. When introducing the practice of PA, $7.3 \%$ of the total variance was explained. As a last step, when introducing the psychosocial aspects of the practice of physical-sporting activity, $9.9 \%$ of the total variance was explained. 
Similarly, it can be seen that $A P$ is associated with high levels of university sports management $(B=0.056$, $p=.1)$, as well as with the practice of $P A(B=.278, p=.13)$ and aspects psychosocial aspects of the practice of physical-sporting activity $(B=.214, p=.12)$.

The model of the 3 dimensions mentioned explains $10 \%$ of the AP with the F statistic equal to 3.98 and a $p$ value equal to .01 , which indicates that the 3 dimensions are predictive, as shown in Table 3 .

Table 3. Multiple regression analysis.

\begin{tabular}{lccc}
\hline Predictors & AP & & \\
\hline Sport practice & Beta (SD) & t & Sig. \\
$\quad$ University sports management & & & \\
$\quad$ PA practice & $0.056(0.1)$ & 0.57 & .57 \\
$\quad$ Psychosocial aspects of the practice of physical-sporting activity & $0.278(0.13)$ & 2.18 & .032 \\
$\mathrm{R}$ & $0.214(0.12)$ & 1.76 & .081 \\
$\mathrm{R}^{2}(\%)$ & 31.4 & & \\
Model & 10 & & \\
\hline
\end{tabular}

\section{DISCUSSION AND CONCLUSIONS}

The purposes of the study were to make a comparison of the levels of sports practice and AP according to the gender of the student, to determine the relationship connecting sports practice, its dimensions and AP; in addition to analysing the inference of sports practice and its dimensions on AP.

A significant difference was found betwixt sports practice and its dimensions in Physical Education students who play soccer in their free time, being higher in the male gender $(p<.05)$. Likewise, a positive and significant association $(r=0.33)$ was obtained linking sports practice and students' AP. Finally, it was found that sports practice and its dimensions influence AP in a positive and significant way $\left(r^{2}=10 \%, p=.01\right)$. These results are similar with Montecalbo-lgnacio et al. (2017), whose study results revealed that a significant relationship betwixt PA and the AP of student-athletes. In addition to Yıldırım and Bayrak (2019) who determined the positive and significant relationship uniting the performance of physical activities based on sport and academic position. In addition to Lipošek et al. (2019), who exhibited that men performed better than women on almost all physical tests and periods of two hours of weekly PA were positively associated with AP. Also, with Muñoz-Bullón et al. (2017), who revealed that participation in PA is associated with higher scores among students at a Spanish college. Similarly, with Al-Drees et al. (2016), who exhibited a significant positive association connecting students' PA habits and high AP $(X 2=10.65)$. As with Fricke et al. (2017) who suggest that students that are better able to integrate study and exercise, can improve study effectiveness and therefore improve AP. Finally, with Qurban et al. (2018) who obtained a direct relationship connecting SP and AP.

This study is not without limitations, among which we can find the descriptive and cross-sectional character, the sample size and the individuals who practice only one type of sport. As a conclusion, it is observed that a better level of AP is influenced by better levels of sports practice and its respective dimensions. Likewise, sports practice is positively and significantly related to AP; finally, the male gender sample has a higher level of sports practice, while the female gender shows a better academic level. 


\section{ACKNOWLEDGEMENTS}

The authors wish to thank the students who participated in the collection of questionnaires, as well as all the participants for their collaboration in the study.

\section{REFERENCES}

Al-Drees, A., Abdulghani, H., Irshad, M., Baqays, A., Al-Zhrani, A., Abdullah, S. and Ibrahim, N. (2016). Physical activity and academic achievement among the medical students: A cross-sectional study. Med Teach, 38(1), S66-S72. https://doi.org/10.3109/0142159X.2016.1142516

Alvarez, G. M., Vargas, M. G., Murillo, H. M. and Amaya, J. R. (2017). Sedentary lifestyle and physical activity in administrative public sector workers. Ciencia Unemi, 9(21), 116-124. https://doi.org/10.29076/issn.2528-7737vol9iss21.2016pp116-124p

Arias, N. M., Solera, M., Gracia, L., Silva, P., Martinez, V., Canete, J. and Sanchez, M. (2015). Levels and Patterns of Objectively Assessed Physical Activity and Compliance with Different Public Health Guidelines in University Students. PLOS ONE, 10(11), e0141977. https://doi.org/10.1371/journal.pone.0141977

Asgari, S. and Carter Jr, F. (2016). Peer Mentors Can Improve Academic Performance: A QuasiExperimental Study of Peer Mentorship in Introductory Courses. Teach Psychol, 43(2), 131-135. https://doi.org/10.1177/0098628316636288

Castillo, E., Abad, M., Giménez, F. J. and Robles, J. (2012). Design of a questionnaire on physical activity habits and lifestyles based on the Delphi method. Spor Sci J, 8(1), 51-66.

Coe, D. P., Pivarnik, J. M., Womack, C. J., Reeves, M. J. and Malina, R. M. (2006). Effect of physical education and activity levels on academic achievement in children. Med Sci Sport Exer, 38(8), 15151519. https://doi.org/10.1249/01.mss.0000227537.13175.1b

Donnelly, J. E. and Lambourne, K. (2011). Classroom-based physical activity, cognition, and academic achievement. Prev Med(52), S36-S42. https://doi.org/10.1016/.ypmed.2011.01.021

Dwyer, T., Sallis, J. F., Blizzard, L., Lazarus, R. and Dean, K. (2001). Relation of Academic Performance to Physical Activity and Fitness in Children. Pediatr Exerc Sci, 13(3), 225-237. https://doi.org/10.1123/pes.13.3.225

Etikan, I., Abubakar, S. and Sunusi, R. (2016). Comparison of Convenience Sampling and Purposive Sampling. Amer J Theor Appl Stat, 5(1), 1-4. https://doi.org/10.11648/i.jitas.20160501.11

Fricke, H., Lechner, M. and Steinmayr, A. (2017). The Effect of Physical Activity on Student Performance in College: An Experimental Evaluation. Stanford Center for Education Policy Analysis: http://cepa.stanford.edu/wp17-03

Gayles, J. G. and Hu, S. (2009). The Influence of Student Engagment and Sport Participation on College Outcomes Among Division I Student Athletes. J High Educ, 80(3), 315-333. https://doi.org/10.1080/00221546.2009.11779015

Georgian, B. and Lorand, B. (2016). The importance sports activities have over the quality of life in the adult population type. J Soc Sci Res, 10(1), 2003-2006. https://doi.org/10.24297//ssr.v10i1.6601

Gill Jr, E. L. and Farrington, K. (2014). The Impact of an Intensive Learning Program (ILP) on Black Male Football Student-Athlete Academic Achievement. J Coll Student Dev, 55(4), 413-418. https://doi.org/10.1353/csd.2014.0037

Khan, S., Khan, I., Farhatullah, Phil, F. and Nasrullah, S. (2014). The Importance of Sports and the Role of the Institutional Head. Int Conf Eng Des, 4(11), 84-87. 
Lipošek, S., Planinšec, J., Leskošek, B. and Pajtler, A. (2019). Physical activity of university students and its relation to physical fitness and academic performance. Ann Kines, 9(2), 89-104. https://doi.org/10.35469/ak.2018.171

McPherson, A., Mackay, L., Kunkel, J. and Duncan, S. (2018). Physical activity, cognition and academic performance: an analysis of mediating and confounding relationships in primary school children. BMC Public Health (18), 936. https://doi.org/10.1186/s12889-018-5863-1

Montecalbo-Ignacio, R., lii, R. and Buot, M. (2017). Academic achievement as influenced by sports participation in selected universities in the Philippines. Educ, 7(3), 53-57.

Muñoz-Bullón, F., Sánchez, M. and Vos, A. (2017). The influence of sports participation on academic performance among students in higher education. Sport Manag Rev, 20(4), 365-378. https://doi.org/10.1016/j.smr.2016.10.006

Nieman, P. (2002). Psychosocial aspects of physical activity. Paediatr Child Health, 7(5), 309-312. https://doi.org/10.1093/pch/7.5.309

Qurban, H., Siddique, H., Wang, J. and Morris, T. (2018). The Relation between Sports Participation and Academic Achievement: The Mediating Role of Parental Support and Self-Esteem. J Human Psychol, 1(1), 27-40. https://doi.org/10.14302/issn.2644-1101.jhp-18-2467

Ramírez, M., Raya, M. and Ruiz, M. (2018). Sedentarismo y salud: efectos beneficiosos de la actividad física en estudiantes universitarios. El J Res Inv Teach(7), 79-84. Retrieved from https://digibug.ugr.es/bitstream/handle/10481/49826/7-7.pdf?sequence=1\&isAllowed=y

Retar, I., Bednarik, J. and Kolar, E. (2015). The definition of sports management. Facta Universitatis, 13(2), 275-281. Retrieved from http://casopisi.junis.ni.ac.rs/index.php/FUPhysEdSport/article/download/1128/987

Şahin, E., Çekin, R. and Yazıcılar, İ. (2018). Predictors of Academic Achievement among Physical Education and Sports Undergraduate Students. Sports, 6(1), 8. https://doi.org/10.3390/sports6010008

Taber, K. (2018). The Use of Cronbach's Alpha When Developing and Reporting Research Instruments in Science Education. Res Sci Educ (48), 1273-1296. https://doi.org/10.1007/s11165-016-9602-2

Taras, H. (2005). Physical Activity and Student Performance at School. J School Health, 75(6), 214-218. https://doi.org/10.1111/j.1746-1561.2005.tb06675.x

Uyanık, G. K. and Güler, N. (2013). A Study on Multiple Linear Regression Analysis. Procd Soc Behv(106), 234-240. https://doi.org/10.1016/i.sbspro.2013.12.027

World Health Organization. (26 de November de 2020). Physical activity: https://www.who.int/newsroom/fact-sheets/detail/physical-activity

Yıldirım, M. and Bayrak, C. (2019). The Participation of University Students in Physical Activities Based on Sport and The Effect of The Students'quality of Life on Academic Achievement and Socialisation (Sample of Eskisehir Osmangazi University). J Educ, 34(1), 123-144. https://doi.org/10.16986/HUJE.2017032928

\section{@)}

This work is licensed under a Attribution-NonCommercial-NoDerivatives 4.0 International (CC BY-NC-ND 4.0). 